\title{
An extract of the medicinal plant Artemisia annua modulates production of inflammatory markers in activated neutrophils
}

This article was published in the following Dove Press journal:

Journal of Inflammation Research

14 January 2015

Number of times this article has been viewed

\author{
Sheena Hunt' \\ Mayumi Yoshida ${ }^{2}$ \\ Catherine EJ Davis ${ }^{2}$ \\ Nicholas S Greenhill ${ }^{2}$ \\ Paul F Davis ${ }^{2}$ \\ 'Promisia Integrative Ltd, Wellington, \\ New Zealand; ${ }^{2}$ Trinity Bioactives Ltd, \\ Wellington, New Zealand
}

Correspondence: Sheena Hunt Promisia Integrative Ltd, Level I5, I7I Featherston Street, Wellington, New Zealand

Tel +64 48948524

Fax +64 48946598

Email sheena@promisia.com
Purpose: To investigate the ability of a commercial extract from the medicinal plant Artemisia annua to modulate production of the cytokine, tumor necrosis factor-alpha (TNF- $\alpha$ ), and the cyclooxygenase $(\mathrm{COX})$ inflammatory marker, prostaglandin $\mathrm{E}_{2}\left(\mathrm{PGE}_{2}\right)$ in activated neutrophils.

Methods: Neutrophils were harvested from rat whole blood and cultured in the presence of plant extract or control samples. Neutrophils, except unactivated control cells, were activated with $10 \mu \mathrm{g} / \mathrm{mL}$ lipopolysaccharide (LPS). The cells were cultured with a range of different concentrations of the $A$. annua extracts $(400-1 \mu \mathrm{g} / \mathrm{mL})$ and artemisinin $(200$ and $100 \mu \mathrm{g} / \mathrm{mL})$ and the supernatants were then tested by enzyme-linked immunosorbent assay (ELISA) for the concentrations of TNF- $\alpha$ and $\mathrm{PGE}_{2}$. Each sample was assayed in triplicate. Positive controls with an inhibitor were assayed in triplicate: chloroquine 2.58 and $5.16 \mu \mathrm{g} / \mathrm{mL}$ for TNF- $\alpha$, and ibuprofen $400 \mu \mathrm{g} / \mathrm{mL}$ for $\mathrm{PGE}_{2}$. An unsupplemented group was also assessed in triplicate as a baseline control.

Results: Neutrophils were stimulated to an inflammatory state by the addition of LPS. A. annua extract significantly inhibited TNF- $\alpha$ production by activated neutrophils in a dose-dependent manner. There was complete inhibition by the A. annua extract at 200,100 , and $50 \mu \mathrm{g} / \mathrm{mL}$ (all $P \leq 0.0003$ ). At $A$. annua extract concentrations of 25,10 , and $5 \mu \mathrm{g} / \mathrm{mL}$, TNF- $\alpha$ production was inhibited by $89 \%(P<0.0001), 54 \%(P=0.0002)$, and $38 \%(P=0.0014)$, respectively. $A$. annua $1 \mu \mathrm{g} / \mathrm{mL}$ did not significantly inhibit TNF- $\alpha$ production $(8.8 \% ; P>0.05)$. Concentrations of 400, 200, and $100 \mu \mathrm{g} / \mathrm{mL}$ A. annua extract significantly inhibited $\mathrm{PGE}_{2}$ production by $87 \%$ ( $P=0.0128), 91 \%(P=0.0017)$, and 93\% $(P=0.0114)$, respectively.

Conclusion: An extract of $A$. annua was shown to be a potent inhibitor of TNF- $\alpha$ and a strong inhibitor of $\mathrm{PGE}_{2}$ production in activated neutrophils at the concentrations tested. Further studies are warranted with this promising plant extract.

Keywords: in vitro, TNF- $\alpha$, COX-2, $\mathrm{PGE}_{2}$, artemisinin, Arthrem

\section{Introduction}

Much recent attention has been given to traditional medicines and natural products with potential and promising anti-inflammatory properties. ${ }^{1-4}$ However, much of the evidence is minimal or anecdotal, and it is clear that more research is needed in this area. ${ }^{2}$

The medicinal plant Artemisia annua L. (Asteraceae) is native to the People's Republic of China but has been introduced and grows wild throughout Asia, North America, and Europe, and is now broadly cultivated for medicinal purposes. ${ }^{5} \mathrm{~A}$. annua has been used as a medicinal herb for more than 2,000 years. ${ }^{6}$ Traditional uses of the plant include as an antimalarial, a food additive, an anti-inflammatory, and to treat 
hemorrhoids, lice, and boils. ${ }^{2}$ Texts on Chinese herbal medicines, written as early as $200 \mathrm{AD}$, also reported that it relieved joint pain. ${ }^{5}$

In the 1970s, researchers in the People's Republic of China identified one of the main components of $A$. annua; a sesquiterpene lactone, artemisinin. ${ }^{5,6}$ Artemisinin-based therapy is one of the most effective agents for the prevention and treatment of malaria and has been used successfully to treat millions of people worldwide..$^{7-11}$ The mechanism of action against malaria is still debated, even though a number of potential targets have been proposed, such as alkylation of heme or proteins, inhibition of a parasite gene, or damage to the parasite's membrane. ${ }^{12}$ The compounds in A. annua appear to have other bioactive properties and may have broader antidisease applications beyond the treatment of malaria. ${ }^{13}$

Artemisinin appears to have anti-inflammatory properties, probably due to the inhibition of inflammatory factors and mediators such as tumor necrosis factor-alpha (TNF- $\alpha$ ), interleukin (IL)-6, IL-1 $\beta$, and nitric oxide. ${ }^{14,15}$ Other antimalarial drugs, especially quinine derivatives, are standard therapies for the treatment of rheumatoid arthritis and systemic lupus erythematosus, where they appear to have both diseasemodifying and anti-inflammatory effects. ${ }^{16}$

The aim of this study was to investigate the ability of an extract of $A$. annua to modulate production of the cytokine TNF- $\alpha$ in activated neutrophils. Preliminary investigations were also conducted on the ability of $A$. annua to modulate production of the cyclooxygenase (COX) inflammatory marker, prostaglandin $\mathrm{E}_{2}\left(\mathrm{PGE}_{2}\right)$ in activated neutrophils. These commonly studied markers were chosen as they are known to be produced by neutrophils from many species and can also be easily studied and quantified using welldocumented in vitro assays.

\section{Materials and methods}

\section{Plant material}

A commercial supercritical carbon dioxide extract of $A$. annua was used in the assays. The extract is used in Arthrem ${ }^{\mathrm{TM}}$ capsules (Promisia Integrative Ltd, Wellington, New Zealand), a dietary supplement for joint support. Commercially available artemisinin capsules (Super Artemisinin; NutriCology, Alameda, CA, USA) were also tested.

\section{Cell culture}

Rat blood was taken by cardiac puncture of animals under an animal ethics protocol approved by the Animal Ethics Committee, University of Otago, Wellington, New Zealand. Blood was collected in an anticoagulant (ethylenediaminetetraacetic acid) tube, inverted several times, and kept at $18^{\circ} \mathrm{C}-22^{\circ} \mathrm{C}$. Polymorphprep ${ }^{\mathrm{TM}}$ (Axis-Shield, Oslo, Norway) $2.5 \mathrm{~mL}$ was added to each centrifuge tube, overlayered with $7.0 \mathrm{~mL}$ whole blood, and centrifuged at $500 \mathrm{~g}$ for 30 minutes at $20^{\circ} \mathrm{C}$. After centrifugation, the polymorphonuclear fraction was suspended with Hank's Balanced Salt Solution (HBSS) and centrifuged at $125 \mathrm{~g}$ for 5 minutes at $4{ }^{\circ} \mathrm{C}$. The supernatant was discarded and the cell pellet was resuspended, washed with $\mathrm{HBSS}$, and centrifuged at $125 \mathrm{~g}$ again. The supernatant was discarded and the cell pellet was resuspended in RPMI-1640 medium (Gibco, Auckland, New Zealand). The cell number was counted and the concentration adjusted to $5.0 \times 10^{6}$ cells $/ \mathrm{mL}$ with RPMI-1640 medium. The cell suspensions containing isolated neutrophils were kept on ice for up to 10 minutes until used in the assays.

\section{Experimental assays}

In the TNF- $\alpha$ assay, $A$. annua extract was tested at a range of concentrations from $200 \mu \mathrm{g} / \mathrm{mL}$ to $1 \mu \mathrm{g} / \mathrm{mL}$. The concentrations of $A$. annua for this dose-response study were selected because preliminary tests (not shown here) indicated that A. annua $400 \mu \mathrm{g} / \mathrm{mL}$ completely inhibited TNF- $\alpha$ production by activated neutrophils. Artemisinin was tested at $200 \mu \mathrm{g} / \mathrm{mL}$ and $100 \mu \mathrm{g} / \mathrm{mL}$. The positive control, chloroquine, was tested at $5 \mu \mathrm{M}(2.58 \mu \mathrm{g} / \mathrm{mL})$ and $10 \mu \mathrm{M}(5.16 \mu \mathrm{g} / \mathrm{mL})$. The investigation into $\mathrm{PGE}_{2}$ production was preliminary, with only three concentrations of $A$. annua tested: $400 \mu \mathrm{g} / \mathrm{mL}, 200 \mu \mathrm{g} / \mathrm{mL}$, and $100 \mu \mathrm{g} / \mathrm{mL}$. The concentrations selected for this analysis were arbitrary as, to our knowledge, there have been no previous reports of $A$. annua modulating the production of $\mathrm{PGE}_{2}$ in activated neutrophils. Artemisinin was tested at $400 \mu \mathrm{g} / \mathrm{mL}$ and $200 \mu \mathrm{g} / \mathrm{mL}$. The positive control, ibuprofen, which is a COX-2 inhibitor, was tested at $400 \mu \mathrm{g} / \mathrm{mL}$.

Plant extracts and positive controls were dissolved in $100 \%$ ethanol. For each sample of plant extract or positive control, $3 \mu \mathrm{L}$ was added to a 96-well plate. The ethanol was allowed to dry and $20 \mu \mathrm{L}$ of HBSS was then added to the test wells. A total of $160 \mu \mathrm{L}$ of the cell suspension was added to each test well. The plate was incubated in a humidified incubator at $37^{\circ} \mathrm{C}$ in $95 \%$ air and $5 \%$ carbon dioxide for 20 minutes. Twenty microliters of lipopolysaccharide (LPS; Sigma-Aldrich Co, St Louis, MO, USA) at $100 \mu \mathrm{g} / \mathrm{mL}$ was added to each well (except the unactivated control cells). The plate was incubated at $37^{\circ} \mathrm{C}$ in $95 \%$ air and $5 \%$ carbon dioxide. After 24 hours, the plate was centrifuged at $44 \mathrm{~g}$ for 5 minutes. A $50 \mu \mathrm{L}$ aliquot from each well was transferred to new 96-well plates for either TNF- $\alpha$ or $\mathrm{PGE}_{2}$ determination and stored at $-20^{\circ} \mathrm{C}$ until used. Each sample was assayed 
in triplicate. As a positive control, triplicate wells with an inhibitor were assayed. As a baseline control, an unsupplemented group was also assessed in triplicate.

\section{Enzyme-linked immunosorbent assay}

The enzyme-linked immunosorbent assays (ELISAs) for TNF- $\alpha$ and PGE $_{2}$ were performed according to the instruction manual provided by the kit manufacturer (R\&D Systems, Inc., Minneapolis, MN, USA) and the absorbance read at $450 \mathrm{~nm}$ using a VersaMax ${ }^{\mathrm{TM}}$ 96-well plate reader.

\section{Statistical analysis}

The percentage standard error of the mean (SEM) for each sample was assessed and extreme outliers were removed if the SEM\% was greater than $15 \%$. Preliminary statistical significance was assessed with an independent Student's $t$-test at $\alpha \leq 0.05$ (with and without outliers).

\section{Results}

In both assays, the addition of the LPS to the neutrophil cells stimulated them to an inflammatory state.

\section{Inhibition of TNF- $\alpha$ production}

For the control cells, the concentration of TNF- $\alpha$ increased 11.89-fold when LPS was included. The positive control, chloroquine, resulted in $23.7 \%$ and $42.6 \%$ reductions in TNF- $\alpha$ production at $5 \mu \mathrm{M}$ and $10 \mu \mathrm{M}$, respectively.
A. annua extract significantly inhibited TNF- $\alpha$ production by activated neutrophils in a dose-dependent manner (Figure 1). There was complete inhibition by the extract at 200,100 , and $50 \mu \mathrm{g} / \mathrm{mL}$ (all $P \leq 0.0003$ ). At 25,10 , and $5 \mu \mathrm{g} / \mathrm{mL}, A$. апnиa extract inhibited TNF- $\alpha$ production by $89 \%(P<0.0001), 54 \%(P=0.0002)$, and $38 \%(P=0.0014)$, respectively. At an $A$. аnnua concentration of $1 \mu \mathrm{g} / \mathrm{mL}, \mathrm{TNF}-\alpha$ production was not significantly inhibited $(8.8 \% ; P>0.05)$. Figure 2 shows a dose-response curve of the percentage inhibition of TNF- $\alpha$ production. Artemisinin at $200 \mu \mathrm{g} / \mathrm{mL}$ and $100 \mu \mathrm{g} / \mathrm{mL}$ inhibited TNF- $\alpha$ production by $40.7 \%$ and $23.2 \%$, respectively. This is less than that seen with the same concentration of the whole $A$. апnиa plant extract.

\section{Inhibition of $\mathrm{PGE}_{2}$}

In control cells, the concentration of $\mathrm{PGE}_{2}$ increased 4.95 -fold compared to unactivated cells. Ibuprofen at $400 \mu \mathrm{g} / \mathrm{mL}$ was a very potent inhibitor of COX-2 activity, with a $91 \%$ reduction in $\mathrm{PGE}_{2}$ production. A. аnnua extract significantly inhibited $\mathrm{PGE}_{2}$ production by activated neutrophils. At concentrations of 400,200 , and $100 \mu \mathrm{g} / \mathrm{mL}, A$. annua extract significantly inhibited $\mathrm{PGE}_{2}$ production by $87 \%(P=0.0128)$, $91 \%(P=0.0017)$, and $93 \%(P=0.0114)$, respectively. Figure 3 shows the effects of the samples on $\mathrm{PGE}_{2}$ inhibition by activated neutrophils. As in the TNF- $\alpha$ assay, artemisinin significantly inhibited production of $\mathrm{PGE}_{2}$, but was not as potent as the whole $A$. апnua extract at the same concentration;

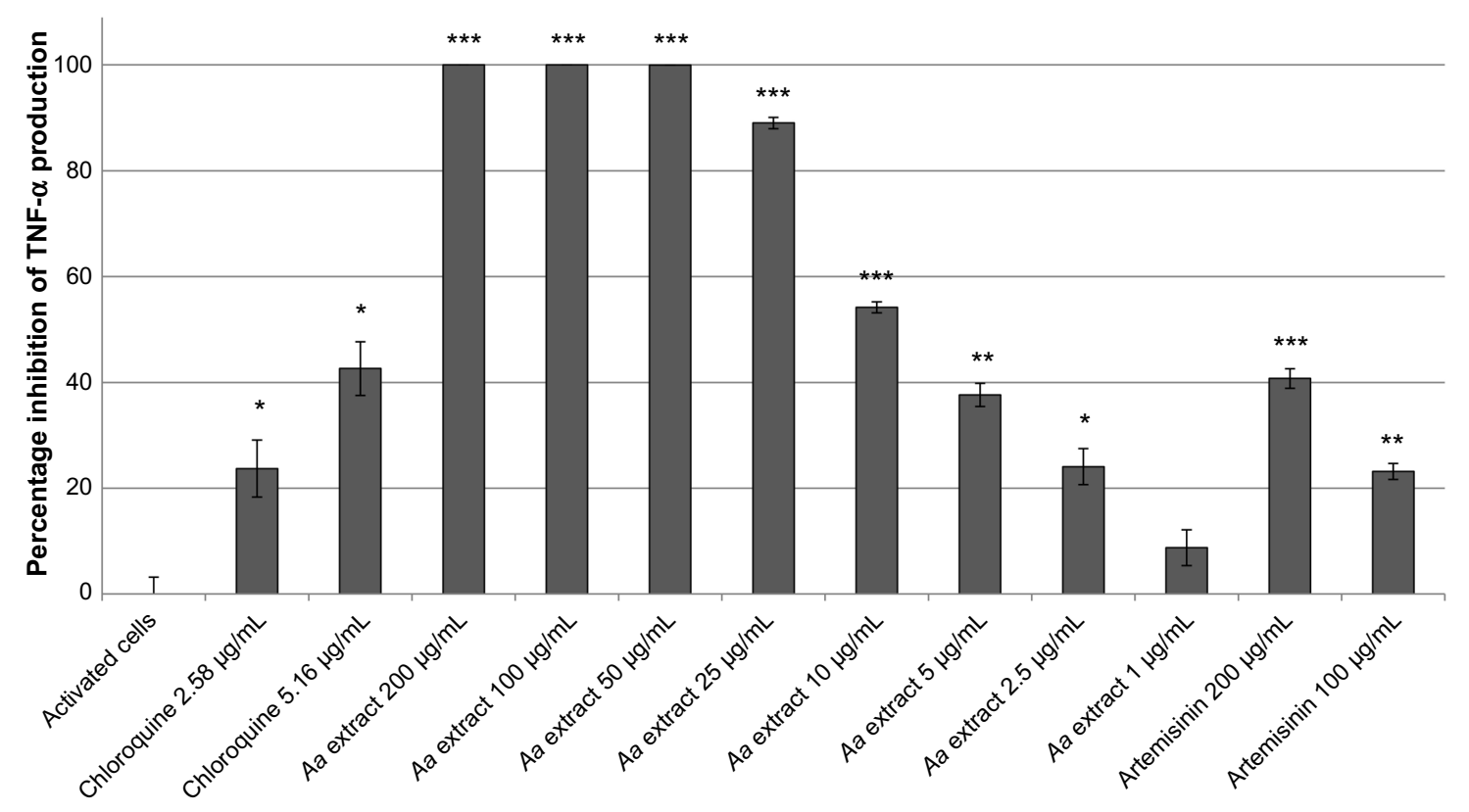

Figure I Percentage inhibition ( \pm standard error) of TNF- $\alpha$ production in activated neutrophils. Notes: $* P \leq 0.05 ; * * P \leq 0.01 ; * * * P \leq 0.001$.

Abbreviations: Aa, Artemisia annua; TNF- $\alpha$, tumor necrosis factor-alpha. 


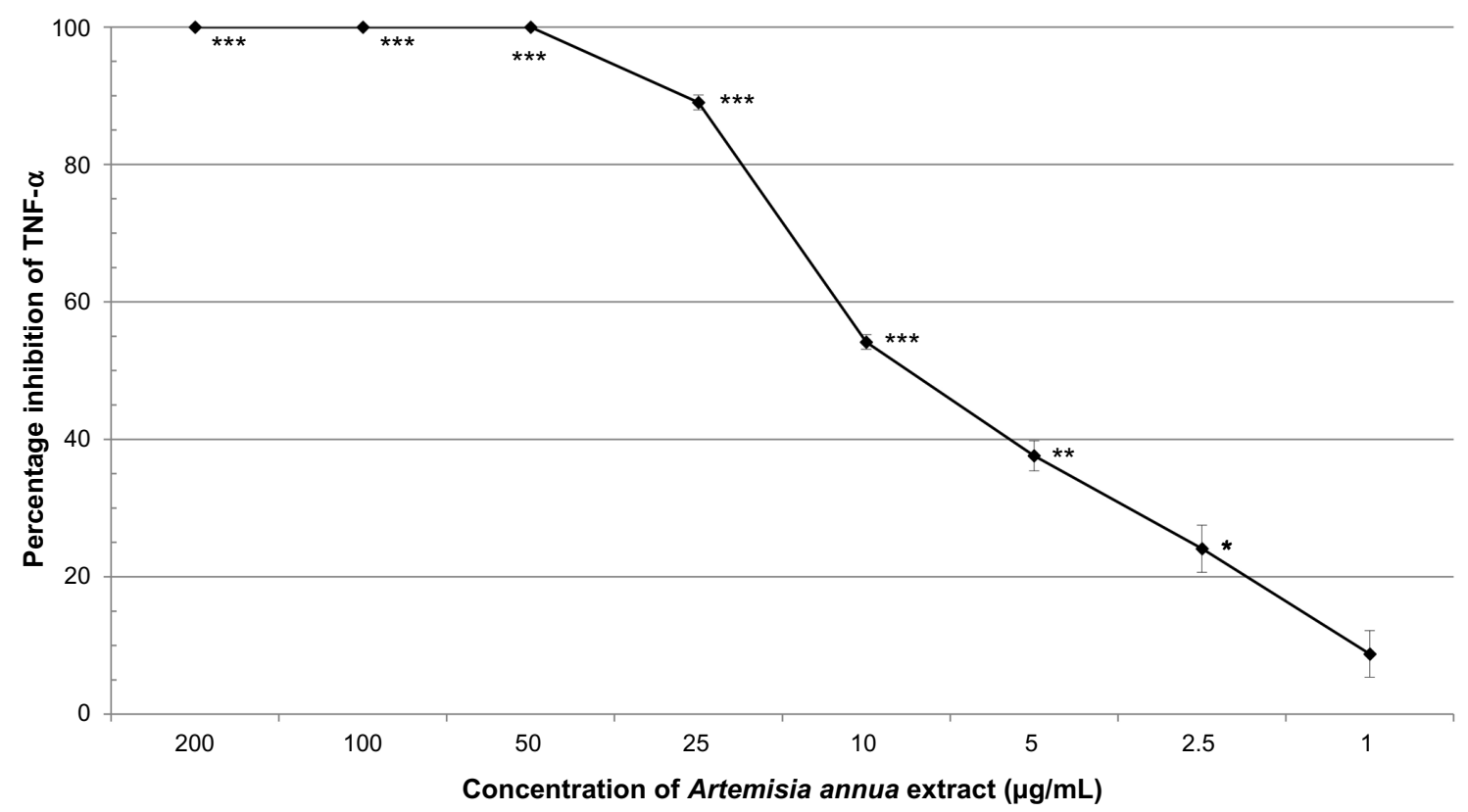

Figure 2 Dose-response of percentage inhibition ( \pm standard error) of TNF- $\alpha$ production in activated neutrophils by Artemisia annua extract. Notes: $* P \leq 0.05 ; * * P \leq 0.01 ; * * * P \leq 0.001$.

Abbreviation: TNF- $\alpha$, tumor necrosis factor-alpha.

artemisinin 400 and $200 \mu \mathrm{g} / \mathrm{mL}$ inhibited $\mathrm{PGE}_{2}$ production by $65 \%(P=0.0063)$ and $57 \%(P=0.0101)$, respectively.

\section{Discussion}

In this study, the $A$. annua extract was shown to be a potent inhibitor of TNF- $\alpha$ by activated neutrophils with a clear dose-response effect. There was complete inhibition of
TNF- $\alpha$ production at concentrations of $50 \mu \mathrm{g} / \mathrm{mL}$ and above. The extract showed statistically significant inhibition of TNF- $\alpha$ production at all concentrations down to $2.5 \mu \mathrm{g} / \mathrm{mL}$ (24\% inhibition).

Artemisinin, a well-established bioactive derived from A. апnиa, also inhibited the production of TNF- $\alpha$ by activated neutrophil cells in this study. However, the artemisinin was

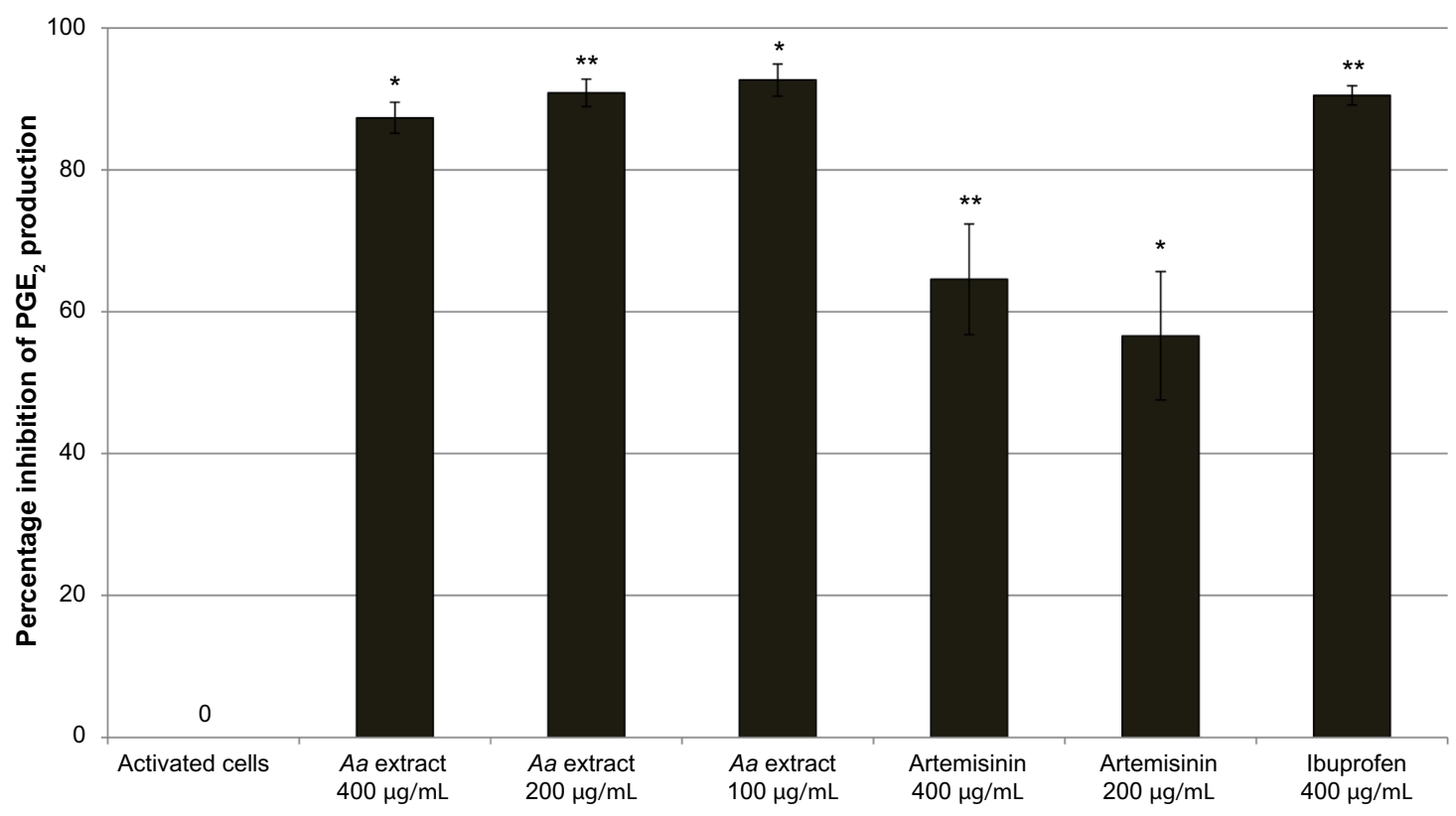

Figure 3 Percentage inhibition ( \pm standard error) of $\mathrm{PGE}_{2}$ production in activated neutrophils. Notes: $* P \leq 0.05 ; * * P \leq 0.01$.

Abbreviations: Aa, Artemisia annua; $\mathrm{PGE}_{2}$, prostaglandin $\mathrm{E}_{2}$. 
not as potent as the whole extract of the plant. The inhibitory effects of $200 \mu \mathrm{g} / \mathrm{mL}$ and $100 \mu \mathrm{g} / \mathrm{mL}$ artemisinin were $40.7 \%$ and $23.2 \%$, respectively, while the equivalent concentrations in the whole plant extract were both $100 \%$ inhibitory. These results suggest that artemisinin is a strong inhibitor of TNF- $\alpha$ production but that it is not the only antagonist present in the plant extract. It appears likely therefore, that other components of the A. annua extract also contribute to its anti-inflammatory bioactivity.

Similar results were seen in the $\mathrm{PGE}_{2}$ assay, with a significant inhibitory effect displayed for all concentrations of the extract tested. Again, the inhibitory effects of the compound artemisinin were not as potent as the effect of the whole plant extract. This suggests again that there are other bioactive components in the $A$. annua extract, as well as artemisinin, that inhibit the COX-2 activity. This was a preliminary investigation of activity at a small number of concentrations of the plant extract. Inhibition of $\mathrm{PGE}_{2}$ was similar for all concentrations of $A$. аппиа extract tested. This implies that 400,200 , and $100 \mu \mathrm{g} / \mathrm{mL}$ A. annua extract produced a maximal level of inhibition. Further investigations on dose-response below $100 \mu \mathrm{g} / \mathrm{mL}$ would be needed to find out the potency of $A$. annua extract at inhibiting $\mathrm{PGE}_{2}$ production.

These results corroborate previous reports suggesting that artemisinin is not the only bioactive compound in A. annиа. ${ }^{17,18} \mathrm{~A}$ review on traditional $A$. апnиа use in malaria suggests that the activity of $A$. апnиa extracts cannot be accounted for by their artemisinin content alone. ${ }^{17}$ Another study suggests that artemisinin may act synergistically with flavonoids and polyphenols also present in A. annua. ${ }^{18}$ It is not known whether either of these classes of compounds are present in the extract tested in this study. Interestingly, in humans, it appears that the bioavailability of artemisinin is enhanced when the entire plant extract is consumed, compared with consumption of pure artemisinin. ${ }^{19}$ It is possible that, of the many types of phytochemicals isolated from A. аппиа (sesquiterpenoids, monoterpenes, triterpenoids, flavonoids, coumarins, phenolics, and lipids), several may be responsible for the overall activity and properties of crude plant $A$. апnиa extracts compared to that of pure artemisinin. ${ }^{5,20}$

While artemisinin may not be responsible for all of the bioactivity in this $A$. апnиa extract, it is likely that it is one of the most important compounds in the extract. Dihydroartemisinin, a semi-synthetic analog of artemisinin, has been reported to significantly inhibit LPS-induced release of TNF- $\alpha$, IL-6, and nitric oxide from mouse mononuclear macrophages. ${ }^{14}$ Pure artemisinin has been reported to have an anti-inflammatory effect on phorbol myristate acetate-induced THP-1 monocytes. ${ }^{15}$

The extract of $A$. annua used in this study seems to have potent bioactivity. This could partly be due to the physical properties of artemisinin, which is poorly water soluble and is heat labile. ${ }^{21}$ The commercial extract used in this study was produced by supercritical extraction of the plant material with carbon dioxide. This type of extraction allows the processing of plant material at low temperatures, limiting thermal degradation, and avoids the use of toxic solvents such as hexane or methane. ${ }^{22,23}$

Studies have previously tested extracts of $A$. аппиа in vitro, with results reporting a variety of bioactive properties, including protection against oxidative stress, ${ }^{24}$ and antioxidant, ${ }^{25}$ anthelminthic, ${ }^{26}$ and anti-pest ${ }^{27}$ properties. However, to our knowledge, this is the first report of in vitro anti-inflammatory properties in this interesting plant.

This study has some limitations. While a dose-response effect was established for TNF- $\alpha$ inhibition in activated neutrophils, the number of concentrations of $A$. annua tested should be increased to establish a dose-response for $\mathrm{PGE}_{2}$. Similarly, artemisinin was only tested at two concentrations in each assay in this study; further studies would be needed to establish a dose-response for artemisinin. This study was conducted only in activated neutrophils; it would be interesting to establish whether the $A$. аппиа extract shows similar activity against the production of other pro-inflammatory cytokines in activated macrophages. Toxicity of the plant extract to activated neutrophils was not assessed; further studies should assess any effect of the medicinal plant on cell survival.

\section{Conclusion}

In this study in activated neutrophils, an extract of $A$. аппиа was shown to be a potent inhibitor of TNF- $\alpha$ and a strong inhibitor of $\mathrm{PGE}_{2}$ production at the concentrations tested. Further studies are needed with this promising plant extract to ascertain whether these in vitro anti-inflammatory effects may translate into in vivo or clinical benefits.

\section{Acknowledgments}

The authors gratefully acknowledge the financial support of a Callaghan Innovation R\&D Project Grant.

\section{Author contributions}

Sheena Hunt designed the study and drafted the manuscript. Mayumi Yoshida and Catherine EJ Davis conducted the 
experiments and analyzed the data. Nicholas S Greenhill supervised the study and analyzed the data. Paul F Davis designed the study, analyzed the data, and helped draft the manuscript. All authors revised the manuscript for important intellectual content and read and approved the final manuscript.

\section{Disclosure}

This study was funded by Promisia Integrative Ltd. Sheena Hunt is an employee of Promisia Integrative Ltd. The other authors report no conflicts of interest in this work.

\section{References}

1. Gautam R, Jachak SM. Recent developments in anti-inflammatory natural products. Med Res Rev. 2009;29(5):767-820.

2. Fürst R, Zündorf I. Plant-derived anti-inflammatory compounds: hopes and disappointments regarding the translation of preclinical knowledge into clinical progress. Mediators Inflamm. 2014;2014:146832.

3. Gu R, Wang Y, Long B, et al. Prospecting for bioactive constituents from traditional medicinal plants through ethnobotanical approaches. Biol Pharm Bull. 2014;37(6):903-915.

4. Salim E, Kumolosasi E, Jantan I. Inhibitory effect of selected medicinal plants on the release of pro-inflammatory cytokines in lipopolysaccharide-stimulated human peripheral blood mononuclear cells. J Nat Med. 2014;68(3):647-653.

5. Willcox M, Bodeker G, Bourdy G, et al. Artemisia annua as a traditional herbal antimalarial. In: Wilcox ML, Bodeker G, Rasoanaivo P, Addae-Kyereme J, editors. Traditional Medicinal Plants and Malaria. Boca Raton, IL: CRC Press; 2004.

6. Graziose R, Lila MA, Raskin I. Merging traditional Chinese medicine with modern drug discovery technologies to find novel drugs and functional foods. Curr Drug Discov Technol. 2010;7(1):2-12.

7. Brown GD. The biosynthesis of artemisinin (Qinghaosu) and the phytochemistry of Artemisia annua L. (Qinghao). Molecules. 2010;15(11):7603-7698.

8. Jelinek T. Artemisinin based combination therapy in travel medicine. Travel Med Infect Dis. 2013;11(1):23-28.

9. Olupot-Olupot P, Maitland K. Management of severe malaria: results from recent trials. Adv Exp Med Biol. 2013;764:241-250.

10. Rathore D, McCutchan TF, Sullivan M, Kumar S. Antimalarial drugs: current status and new developments. Expert Opin Investig Drugs. 2005;14(7):871-883.

11. World Health Organization. WHO informal consultation with manufacturers of artemisinin-based pharmaceutical products in use for the treatment of malaria. Geneva, Switzerland: World Health Organization; 2007. Available from: http://www.who.int/malaria/publications/mtgm anufacturersartemisininderivatives.pdf. Accessed August 29, 2014.
12. O'Neill PM, Barton VE, Ward SA. The molecular mechanism of action of artemisinin - the debate continues. Molecules. 2010;15(3): 1705-1721.

13. Krishna S, Bustamante L, Haynes RK, Staines HM. Artemisinins: their growing importance in medicine. Trends Pharmacol Sci. 2008;29(10):520-527.

14. Yu WY, Kan WJ, Yu PX, Li MM, Song JS, Zhao F. [Anti-inflammatory effect and mechanism of artemisinin and dihydroartemisinin]. Zhongguo Zhong Yao Za Zhi. 2012;37(17):2618-2621. Chinese.

15. Wang Y, Huang Z, Wang L, et al. The anti-malarial artemisinin inhibits pro-inflammatory cytokines via the NF- $\kappa \mathrm{B}$ canonical signaling pathway in PMA-induced THP-1 monocytes. Int J Mol Med. 2011;27(2):233-241.

16. Bellamy N, Brooks PM. Current practice in antimalarial drug prescribing in rheumatoid arthritis. $J$ Rheumatol. 1986;13(3):551-555.

17. Rasoanaivo P, Wright CW, Willcox ML, Gilbert B. Whole plant extracts versus single compounds for the treatment of malaria: synergy and positive interactions. Malar J. 2011;10 Suppl 1:S4.

18. Ferreira JF, Luthria DL, Sasaki T, Heyerick A. Flavonoids from Artemisia annua L. as antioxidants and their potential synergism with artemisinin against malaria and cancer. Molecules. 2010;15(5):3135-3170.

19. Räth K, Taxis K, Walz G, Gleiter CH, Li SM, Heide L. Pharmacokinetic study of artemisinin after oral intake of a traditional preparation of Artemisia annua L. (annual wormwood). Am J Trop Med Hyg. 2004; 70(2):128-132.

20. Bhakuni RS, Jain DC, Sharma RP. Phytochemistry of Artemisia annua and the development of artemisinin-derived antimalarial agents. In: Wright CW, editor. Artemisia. London, UK: Taylor and Francis; 2002.

21. Cui L, Su XZ. Discovery, mechanisms of action and combination therapy of artemisinin. Expert Rev Anti Infect Ther. 2009;7(8):999-1013.

22. Capuzzo A, Maffei ME, Occhipinti A. Supercritical fluid extraction of plant flavors and fragrances. Molecules. 2013;18(6):7194-7238.

23. Coelho JP, Cristino AF, Matos PG, et al. Extraction of volatile oil from aromatic plants with supercritical carbon dioxide: experiments and modeling. Molecules. 2012;17(9):10550-10573.

24. Kim MH, Seo JY, Liu KH, Kim JS. Protective effect of Artemisia annua L. extract against galactose-induced oxidative stress in mice. PLoS One. 2014;9(7):e101486.

25. Iqbal S, Younas U, Chan KW, Zia-Ul-Haq M, Ismail M. Chemical composition of Artemisia annua L. leaves and antioxidant potential of extracts as a function of extraction solvents. Molecules. 2012;17(5): 6020-6032.

26. Cala AC, Ferreira JF, Chagas AC, et al. Anthelmintic activity of Artemisia annua L. extracts in vitro and the effect of an aqueous extract and artemisinin in sheep naturally infected with gastrointestinal nematodes. Parasitol Res. 2014;113(6):2345-2353.

27. Chagas AC, Georgetti CS, Carvalho $\mathrm{CO}$, et al. In vitro activity of Artemisia annua L (Asteraceae) extracts against Rhipicephalus (Boophilus) microplus. Rev Bras Parasitol Vet. 2011;20(1):31-35.
Journal of Inflammation Research

\section{Publish your work in this journal}

The Journal of Inflammation Research is an international, peer-reviewed open-access journal that welcomes laboratory and clinical findings on the molecular basis, cell biology and pharmacology of inflammation including original research, reviews, symposium reports, hypothesis formation and commentaries on: acute/chronic inflammation; mediators of inflamma-

\section{Dovepress}

tion; cellular processes; molecular mechanisms; pharmacology and novel anti-inflammatory drugs; clinical conditions involving inflammation. The manuscript management system is completely online and includes a very quick and fair peer-review system. Visit http://www.dovepress.com/ testimonials.php to read real quotes from published authors. 